\title{
Leisure studies is for experience, not for industry
}

By: Justin Harmon

Harmon, J. (2018). Leisure studies is for experience, not for industry. Scholé: A Journal of Leisure Studies \& Recreation Education, 33(2), 47-54. doi: 10.1080/1937156X.2018.1513272.

Made available courtesy of Taylor \& Francis:

https://doi.org/10.1080/1937156X.2018.1513272

This is an Accepted Manuscript of an article published by Taylor \& Francis in Scholé: A Journal of Leisure Studies \& Recreation Education on 20 December 2018, available online: http://www.tandfonline.com/10.1080/1937156X.2018.1513272

***@ 2018 National Recreation and Park Association. Reprinted with permission. No further reproduction is authorized without written permission from Taylor \& Francis. This version of the document is not the version of record. Figures and/or pictures may be missing from this format of the document. ***

\begin{abstract}
:
In the last decade, some in the field of leisure studies have embraced the experience economy/industry model introduced by Pine and Gilmore (2011) in the late 1990s. While tenets of the experience industry can be found earlier in leisure studies, especially in regards to programing and event management, the idea that experiences should be manufactured for leisurists has become in vogue. This is clearly evidenced by programs at Brigham Young University and California Polytechnic State University in San Luis Obispo, which have both changed their departmental names to reflect the embrace of this ethos. This article critiques the experience industry model and points out the collateral damage that will befall the field, and society, if the concept is embraced throughout the field.
\end{abstract}

Keywords: Experience | experience industry | leisure | inauthenticity

Article:

It is vital that more experiences in the future be available only by admission, for such holds the key to a full-fledged experience economy.

(Pine \& Gilmore, 2011, p.xv).

\section{Introduction}

Charles K. Brightbill was a seminal figure in the field of leisure studies. For many, his classic works set the foundation for the field to build on, largely responsible for its early successes. For Brightbill (1960), the point of reference for all leisure education was deeply seeded in values. He said that 
Our decisions are based on our values and our values are never more on display than they are in our choices of the things we do to satisfy ourselves. Hence leisure not only provides the opportunity to shape values; it also establishes a setting for expressing them. (p. 46)

While there are clearly conflicting visions of the intents and purposes of the field of leisure studies, as has been evidenced with the loss of leisure from the department names of many (if not most) programs, and the shifting embrace of "experience" industry/economy/management in its place, the question of our purpose is imperative. Is it to teach students how to help others in their personal growth and the constructive development of their communities (not to mention their own lives)? Or is it to teach people how to be better consumers? According to some, the latter is our path forward (Rossman, 2007; Rossman \& Ellis, 2012; Ellis \& Rossman, 2008). These scholars and others have fully embraced the Pine and Gilmore (2011) experience economy as the savior of the field. Sylvester (2008), however, starkly warned that if we sacrifice our field to this market model, we have usurped the potential of leisure to contribute to the growth and development of individuals and their communities.

Charles K. Brightbill (1960) said that "Free choice is the heart of leisure" and that it "frees [our] souls... Interests and capacities can be stimulated, but they cannot be imposed ... the desire must come from within. Unless it does, there is no real freedom of choice and no enjoyment and no satisfaction" in life (p. 109). So as we think about the future of the field of leisure studies and its ability to affect the masses, we need to take a clear stance on our motivation: Will it be on the integrity of the individual and society, or in the interests of the industry?

\section{Literature review}

Critiquing the experience industry model

Pine and Gilmore's (2011) Experience economy: Work is theater and every business a stagewas first released in the late 1990s. While the "staging of experiences" had been theorized earlier in the broad field of leisure studies (Rossman, 1995), it was not until their book was first released (1999) that a steady shift was acknowledged in the field. What used to be called leisure departments in the academy had slowly started to splinter with the growth of sub-foci areas like event management and youth development, something that was prophesied by Burdge (1985) over 30 years ago. One clear example is the University of Illinois' once-named Department of Leisure Studies; by the early 2000s, it had changed its name to the Department of Recreation, Sport, and Tourism, in no small part due to the marketability and perceived prestige associated with the name change (Parr \& Schmalz, forthcoming). And while any good business must respond accordingly to the marketplace - in this case the demands of students and their parents - as a field we need to know exactly why it is that we are making these decisions and how those we hope to benefit will be affected by them. If we are to follow Pine and Gilmore's (2011) thinking, then our students, our friends, our family, and our neighbors are all simply pawns to be manipulated in our marketplace stage. To be fair in this critique, then, we will respond to their metaphor in due form and begin our query of Pine and Gilmore's (2011) work with their insistence on the importance of staging and representation as the primary mechanism 
for engaging in "transactional" relationships. While there certainly exists parallels between theater and commerce, we must start with a brief refresher on the originator of this connection, Erving Goffman (1959). Pine and Gilmore start on shaky ground with their misappropriation of the work of Erving Goffman's, a significant theoretical component of their thesis, so we begin there.

\section{Impression management}

Pine and Gilmore (2011) stated that "impressions are the takeaways of the experience; what you want customers to have in their mind after an experience" (p. 78, emphasis added). This assertion begets the question of why a leisure provider thinks they could or shouldattempt to control the outcome of an individual's experience. While we may provide activities, we do not provide meanings. To think otherwise would be misguided, inauthentic, and misleading. For Pine and Gilmore (2011), whose thesis is clearly rooted in the concepts that Goffman (1959) developed, they pick and choose to suit their needs. One glaring oversight involves their interpretation of "authenticity" and how they apply the concept in mediating relationships. For Goffman, authenticity was not something that was ever truly available to any public audience. It should also be noted that acting, after all, is intended to make others believe something that is not true. According to Goffman, impression management, which is really the load-bearing pillar of Pine and Gilmore's (2011) experience economy, is the conscious process by which people attempt to influence the perceptions of others about another person, place, or event. So if we manipulate an activity to impact the quality of an experience, even if it is done with the best of intentions, the understanding and embodiment of that experience is rendered inauthentic. That should not be something for which we strive. While we cannot avoid impacting people's experience to some degree through education or programing, caution is warranted when industry imposition attempts to usurp the freedom of choice and experience.

Sticking with the metaphorical association of leisure providers and educators as actors, Goffman (1959) said that "performers seek certain ends in their interest" (p. 238) in order to manipulate the audience (students, the public) into an agency-desired outcome. When you can predict and control the outcomes, you can streamline the inputs and create an efficiency that favors the producer over the consumer. Goffman went on to say that the front region, or "stage," is where a carefully orchestrated performance is designed to placate the viewing public. Reflecting back to the early thinkers in our field, such as Brightbill $(1960,1961)$, this idea is anathema to the concept of leisure, and thus the field that seeks to promote and educate about the benefits of leisure.

\section{Experience industry in practice}

In his anti-Disney treatise, Dick Hebdige (2003) wrote about the "theming" that was omnipresent and imperative to the success of the fantasyland franchise. Staging any event or "experience" requires "imbuing time with the semblance of significance in order to control projected outcomes" (p. 151). These desired outcomes were threefold: to develop brand loyalty, to reduce consumers to a childlike state of unquenchable wants, and the ultimate return to the point of sale, or product. The reality is that the "innocent bystanders" are "dupes" in a "carnival" of carefully orchestrated designs that leave them less knowledgeable and more likely numbed than satiated 
through the sleight of hand and misrepresentations of the "experience" in which they just took part (p. 153). Hebdige said that Disney, and its counterparts, are raising cattle, "not for the slaughter, but to graze the verdant malls and media-ways ... forever ... to graze and blink and wear the brand" (p. 164). For those that embrace the ethos of the experience economy, this should give them pause: Disney is successful not because they have figured out how to make a visit to their resorts rewarding or life-changing but because they have figured out how to make you think they did.

As Neil Postman (2009) said about Aldo Huxley's (2006) Brave New World, "What afflicted the people in Brave New World was not that they were laughing instead of thinking, but that they did not know what they were laughing about and why they stopped thinking" (p. 163). This is not to discount the agency of the "consumer"-if we choose to speak in those terms - but to highlight the simple fact that you can only grow to the extent of your nourishment. The structural systems we adopt and enforce, such as the experience economy, affect the agency and autonomy of the populace. Sewell (1992) said that structure builds other areas of our social existence, such as gender structuring employment opportunities or class structuring politics. So if our field is to embrace the experience economy, then we must accept that it is at the expense of limiting agency, thus structuring leisure experience to the behest of the provider, and against the autonomy of the leisureist.

This is what Pine and Gilmore (2011) embrace as the standard-bearer of their model. It also leads to another critique: that charging admission (p. 93), charging for anything that was once free (p. 100), charging for time like a lawyer (p. 283), or simply their blanket statement that "you are what you charge for" (p. 100) is something that should be heralded as a virtue. If the experience economy is to be the saving grace of leisure studies, then we must accept and admit that in large part we will only be there to serve those that can afford to continue to pay into the system. For as Pine and Gilmore state, "It is vital that more experiences in the future be available only by admission, for such holds the key to a full-fledged experience economy" (p. xv). The overemphasis on the bottom line, of what else we should be charging for in order to generate more revenue, is anathema to what the field of leisure studies should have at its foundation. Any economy will pit the haves against the have nots, a problem we must confront and would be well-advised to eradicate from our purpose.

Matthew Crawford (2014) said that "The question of what we attend to is a question of what we value" (p. 5), seemingly an echo of Brightbill's early assertions (1960) of the field of leisure studies. He went on to say that in our current day we are at the mercy of "choice architects" who channel our attention for their own interests and develop rationalized systems, which in the end are dehumanizing. George Ritzer (1993) said formal rationality is "the search for the optimum means to a given ends shaped by the rules, regulations, and larger social structures" (p. 19). Using this as his foundation for his McDonaldization thesis, Ritzer (1993) indicated that the process of McDonaldization is driven by economic goals that become enculturated and the accepted default setting of the masses because those that pull the strings hold more power when there is "less room for individual variation" (p. 19). And while Pine and Gilmore (2011) claim mass customization is the essence of their model, if we are being honest, this is an unsustainable, if not simply unattainable, expectation. Something cannot be public and private and personal at the same time. This is not to say that the field of leisure studies cannot benefit from certain 
aspects of the experience economy in programing or event management, but that the ideology cannot be given cart blanche to redirect the missions of social and environmental justice, inclusion, community development, or quality-of-life issues through the edifying properties of leisure. Leisure deals in subjects, not objects.

\section{Calling the "experience industry" what it really is}

When we treat the time, energy, interest, attention, and experiences of others as a resource, it leads to the commodification of the individual. It should be clear that our happiness and growth are not a resource to be harvested, though Pine and Gilmore (2011) appear to think otherwise. First, it must be pointed out that the fundamental principle of any economy is that the currency has to be scarce (Davenport \& Beck, 2001). The scarcest resource these days would be time (Maines, Sugrue, \& Katovich, 1983). For Brightbill (1960), time is the essence of leisure. Marketers continually assault our attention with options for us to consider to embark on in our free-time; the temporal spaces where our field should be promoting growth through leisure. Instead, we see the influence of the experience economy and its goal of persuading people to spend more in the hopes of having rewarding experiences resulting in lasting memories, and doing so under the prescriptive authority of an all-knowing agency. Pine and Gilmore (2011) state this quite explicitly: "As the world progresses further into the experience economy, much that was previously attained through noneconomic activity will increasingly be found in the domain of commerce" (p. 242).

Like any good scholars, though, Pine and Gilmore (2011) do give directions for the future. In the earliest pages of the book they label the progress of the commercial sector as one that evolved from commodities, to goods, to services, to now experiences, and ultimately to transformations. But why do they make a pit-stop at experiences? Why not go straight to the transformation economy if that is the logical progression? Secondly, is the transformation economy not what we have been supposedly doing all along anyways? They state that, "Transformations guide the individual toward realizing some aspiration and then help to sustain that change through time" (p. 277). They continue, "If you charge for the demonstrated outcome the customer achieves, then and only then are you in the transformation business" (p. 283). Of course. It always comes back to money. Why they had to look forward to the transformation economy is because the experience economy will not be able to retain its customers. Pretty soon people will wake up and realize they are being had. Much like the protagonist in Brave New World, eventually people will stop taking their happy pills and realize that all they do is mask their discontent in their lives through premeditated and orchestrated experiences not capable of stimulating growth, either personal or communal. If we are always looking for the next best thing, or the newest gimmick, then we will miss the opportunities before us. We will clear-cut the forest and wonder what happened to the scenery.

\section{Implications for the field of leisure studies}

Near the conclusion, Pine and Gilmore (2011) state: 
As the experience economy naturally progresses into the transformation economy, even experience stagers will find their offerings commoditized as more and more businesses charge explicitly for the demonstrated outcomes they elicit. (p. 294)

If we try to contextualize this assertion with the field of leisure studies, is the next logical step to streamline the education process to make it easier to get more students through the doors in less time, thus resulting in more money for colleges and universities? In some ways we see this in the academy already in the form of online "education" and overburdened sections of courses where students get far less attention than they deserve-and pay for. When we look at the students in our field, what is it that we want to impart upon them: that our field is about the bottom line or about the greater good? If we are solely motivated by economic growth then there really is no reason why our field should not be fully absorbed into a business school. What should set leisure and recreation providers apart from their business school counterparts is that there is some visceral investment in individuals and communities. In regards to leisure education, and through the eyes of Pine and Gilmore (2011), if "[we] are what [we] charge for," then we should be concerned that we are selling a watered down product to a dehydrated and desperate population.

The broad field of leisure studies continues to be pulled in many directions for many reasons, but in no small part because of the splintering into "little leisures" (Parr \& Schmalz, forthcoming). We have lost a shared foundation, or perhaps Godbey's (1985) hand of leisure that connects the fingers of the sub-foci. Because of this, the fractured field continually tried to reinvent itself, grasping at whatever scattered debris we can find, most notably Pine and Gilmore's (2011) experience economy. Embracing the experience industry model will make leisure educators obsolete; after all, the model is about efficiency if nothing else. Why are we needed to teach the economics of competition and streamlining if the business schools are already doing so? But more importantly, we need to be concerned about what embracing the model will do to communities, diversity, progress, and happiness.

To draw one more time from Pine and Gilmore (2011), "To stage compelling esthetic experiences, designers must acknowledge that any environment designed to create an experience is not real. They should not try to fool their guests into believing it is something it is not" (p. 55, emphasis added). And while it appears they unwittingly acknowledge the flaw in their ways, the likely interpretation should be less that it was said as a gaffe and more that it was said tongue in cheek. We should not be in the business of sapping authentic opportunities and experiences from people: students, patrons, community members, no one. Period.

\section{Conclusion}

Transformations can only come from truly authentic experiences. Brightbill (1960) said that leisure is "permanently fertile ground for self-realization. It is a perpetual foundation for discovering new interests and for uncovering hidden talents, for developing new skills, and reviving old interests" (p. 76). He went on to say that, "Educational attainment and learning cannot be accelerated by running them through a cash register" (p. 94). When the bottom line is the bottom line, the potential for existential growth is dismissed. Pine and Gilmore (2011) said, "Impressions are the takeaways of the experience - what you want customers to have in their minds after an experience" (p. 78). Essentially they advise the pillaging of authenticity through 
the creation of carefully designed simulacrums of engagement where the producer scripts the meaning. Pine and Gilmore curiously stated that "There's no such thing as an artificial experience" (p. 54); but I disagree, especially when you look at it through their lens. How you could truly mass customize anything is unfathomable (Sylvester, 2008). But if your organization's overarching principles are rooted in economic growth, then it implies that there necessarily will be a manipulation of the product, service, and interactions with your customers to maximize revenue. It follows, then, with this model, that the only experiences you can provide are ones that are artificial.

Brightbill (1961) said:

If leisure is a threat to society, and it is, it is not because there is so much of it but because we lack the know-how of using it constructively. Too many of are using it to escape life and not enough of us are using it to enrich our lives. (p. 22)

But it may not be that we as consumers are not using it to enrich our lives so much as we as producers are preventing others from doing so purely for our fiscal goals. Pine and Gilmore (2011) champion the plague of themed restaurants, the upselling of memorabilia with the intention of "socializing" the experience for its customers, and the modularization of goods and services in order to be able to "customize" to the desires of its guests. The experience economy is void of any truly authentic component in its model, unless, that is, you consider their authenticity in being inauthentic. Hebdige (2003) warned against "Dis-gnosis" or the dishonesty that is inherent to the business model of Disney. If authenticity is the effective means of claiming identity (Zukin, 2008), then it cannot be found in a model that explicitly states that "your experience will never be worth charging admission for until you explore how to stop giving it away for free" (Pine \& Gilmore, 2011, p. 93). For if everything is an experience, then nothing is. If the experience economy model is fully embraced by the field of leisure studies, then we will encourage competition in the marketplace of staged experiences that will create an artificial value system where it becomes wholly impossible for people to truly grow through leisure, not to mention that many will not be able to afford to participate in the first place.

In closing, Brightbill and Mobley (1966) asked, "What is the purpose of education? [Is it] to make us better producers?" (p. 115). Perhaps we should also ask what the purpose of leisure is. Is it to make us better consumers? The field of leisure studies needs to rethink its embrace of the experience economy model. Not only is the model incapable of providing stability or direction but it would only further alienate the growth potential for individuals and communities, which is the champion cause of the field of leisure studies.

\section{Acknowledgement}

A special thanks to Dr. Charlie Sylvester of Western Washington University and Dr. David Scott of Texas A\&M University for critiquing drafts of this article.

\section{References}

Brightbill, C. K. (1960). The challenge of leisure. Englewood Cliffs, NJ: Prentice-Hall. 
Brightbill, C. K. (1961). Man and leisure: A philosophy of recreation. Englewood Cliffs, NJ: Prentice-Hall.

Brightbill, C. K., \& Mobley, T. A. (1966). Educating for leisure-centered living. New York: Wiley and Sons.

Burdge, R. J. (1985). The coming separation of leisure studies from parks and recreation education. Journal of Leisure Research, 17(2), 133-141.

Crawford, M. B. (2014). The world beyond your head: On becoming an individual in an age of distraction. New York: Farrar, Straus, and Giroux.

Davenport, T. H., \& Beck, J. C. (2001). The attention economy: Understanding the new currency of business. Cambridge, MA: Harvard Business Review Press.

Ellis, G. D., \& Rossman, J. R. (2008). Creating value for participants through experience staging: Parks, recreation, and tourism in the experience industry. Journal of Park and Recreation Administration, 26(4), 1-20.

Godbey, G. (1985). The coming cross-pollination of leisure studies and recreation and park education: A response. Journal of Leisure Research, 17(2), 142-148. doi:

https://doi.org/10.1080/00222216.1985.11969622

Goffman, E. (1959). The presentation of self in everyday life. New York: Anchor.

Hebdige, D. (2003). Dis-gnosis: Disney and the re-tooling of knowledge, art, culture, life, etc. Cultural Studies, 17(2), 150-167.

Huxley, A. (2006). Brave new world. New York: Harper.

Maines, D. R., Sugrue, N. M., \& Katovich, M. A. (1983). The sociological import of G.H.

Mead's theory of the past. American Sociological Review, 48(2), 161-173. doi:

https://doi.org/10.2307/2095102

Parr, M., \& Schmalz, D. L. (forthcoming). Leisure studies and academic houses: Straw, sticks, or bricks? Intended for Leisure Sciences.

Pine, B. J., \& Gilmore, J. H. (1999/2011). The experience economy: Work is theater \& every business a stage. Cambridge, MA: Harvard Business Review Press.

Postman, N. (2009). Amusing ourselves to death: Public discourse in the age of show business. London: Penguin.

Ritzer, G. (1993). The McDonaldization of society: An investigation into the changing character of contemporary social life. Newbury Park, CA: Pine Forge Press.

Rossman, J. R. (1995). Recreation programming: Designing leisure experiences. Urbana, IL: Sagamore Publishing.

Rossman, J. R. (2007). The pursuit of happiness: Programming in the experience economy in the 21 st century. George D. Butler lecture presented at the National Recreation and Park Association Annual Congress, Indianapolis, IN. 
Rossman, J. R., \& Ellis, G. D. (2012). Thoughts on experience: Introduction to the special issue. Journal of Park and Recreation Administration, 30(3), 1-6.

Sewell, W. H. Jr., (1992). A theory of structure: Duality, agency, and transformation. American Journal of Sociology, 98(1), 1-29.

Sylvester, C. (2008). The ethics of experience in recreation and leisure services. Journal of Park and Recreation Administration, 26(4), 21-41.

Zukin, S. (2008). Consuming authenticity. Cultural Studies, 22(5), 724-748. doi:

$10.1080 / 09502380802245985$ 